\author{
잣버섯 신품종 『곤지 10 호』 특성 \\ 전대훈 $^{*} \cdot$ 장명준 ${ }^{2} \cdot$ 하태문 $^{1} \cdot$ 이윤혜 ${ }^{1} \cdot$ 최종인 $^{1} \cdot$ 주영철 $^{2} \cdot$ 유영복 $^{3}$ \\ ${ }^{1}$ 경기도농업기술원 버섯연구소, ${ }^{2}$ 경기도농업기술원 환경농업연구과, ${ }^{3}$ 농촌진흥청 국립원예특작과학원 인삼특작부 버섯과
}

\title{
Characteristics of a new variety $『$ Gonji10ho』 in Neolentinus lepideus
}

\author{
Dae-Hoon Jeon ${ }^{1 *}$, Myoung-Jun Jang ${ }^{2}$, Tai-Moon $\mathrm{Ha}^{1}$, Yun-Hae Lee ${ }^{1}$, \\ Jong-In Choi ${ }^{1}$, Young-Cheul $\mathrm{Ju}^{2}$ and Young-Bok $\mathbf{Y o o}^{3}$ \\ ${ }^{I}$ Mushroom Research Institute, Gyeonggi-Do ARES, 464-870, Korea \\ ${ }^{2}$ Environmental Agriculture Research Division, Gyeonggi-Do ARES, 445-784, Korea \\ ${ }^{3}$ Mushroom Research Division, National Institute of Horticultural \& Herbal Science, RDA, 441-707, Korea
}

(Received September 16, 2013 / Revised December 23, 2013 / Accepted December 31, 2013)

\begin{abstract}
Gonji10ho', a new variety of Neolentinus lepideus, was bred by mating two monokaryotic strains isolated from 'GMNL66037' and 'GMNL66014' in Mushroom Research Institute, Gyonggi-Do ARES in 2012. The optimum temperature for the mycelial growth of 'Gonji10ho' was $29^{\circ} \mathrm{C}$ on PDA medium and that for the primordia formation and the growth of fruiting body of 'Gonji10ho' was $20 \pm 1^{\circ} \mathrm{C}$. In bottle cultivation of 'Gonji10ho', the period of spawn running was around 35 days at $22 \pm 1^{\circ} \mathrm{C}$ and the period from scratching of inoculum to harvesting was 27 days. 'Gonji10ho' had thicker pileus and stipe than control variety('Solhyang'). The number of available stipe was fewer than that of control variety. During the cultivation of 'Gonji10ho', the occurrence rate of Trichoderma spp. was lower than that in control variety. In bottle cultivation, the yield of fruiting bodies of 'Gonji10ho', which was $38 \%$ higher than that of control variety, was $69.6 \mathrm{~g} / 900 \mathrm{ml}$ bottle, and in bag cultivation, that of 'Gonji10ho', which was $10 \%$ higher than that of control variety, was $114.2 \mathrm{~g} / 1 \mathrm{~kg}$ bag. In physical characteristics, the strongness and brittleness of the pileus of 'Gonji10ho' were higher than those of control variety. When considered in the period available for sale, the shelf life of 'Gonji10ho', which was 5 days longer than that of control variety, was 34 days.
\end{abstract}

KEYWORDS - Neolentinus lepideus, Gonji10ho, New variety

\section{서 론}

잣버섯(Neolentinus lepideus)은 구멍장이버섯과에 속하는 버섯으로 세계 대부분의 지역에 걸쳐 분포하 며 이른 여름부터 가을에 걸쳐 침엽수의 그루터기, 고목, 생나무에서 단생 혹은 속생한다(장, 2011). 갓 은 연황색이며 대는 연미색으로, 생육 시 강한 향기 를 발산하며 빛을 보면 갓이 일찍 피는 특성이 있다. 효능에 있어서 포도상구균에 대한 강한 항균력을 가 지며(김, 1979), 조혈 및 면역 활성화(Jin 등, 2003a; Jin 등, 2003b; Choi 등, 2006), 항암, 항바이러스, 혈 압강하, 간기능 개선(진과 정, 1999) 등의 효과가 있 다고 보고되어 있다. 요리 시 솔향이 나며 쫄깃쫄깃 한 씹는 맛이 살아있어 식미가 우수하다.

과거에 잣버섯은 재배가 이루어지지 않았으나 연중
안정생산체계 구축을 위해 경기도농업기술원 버섯연 구소에서 재배기술을 개발하였으며(장 등, 2010a, 장 등, 2010b) 최근 경기도 가평지역을 중심으로 재배를 시도하고 있다. 또한 버섯연구소에서 품종 개발 연구 도 이루어져 2009년 다발성 품종인 ‘솔향’을 육성하 였다(장 등, 2010c). 그러나 수량이 낮은 단점이 있어 서 이 단점을 보완하고 품질이 우수한 잣버섯 신품종 '곤지 10 호'를 육성하였기에 결과를 보고하고자 한다.

\section{재료 및 방법}

'곤지 10 호'의 육성과정은 Fig. 1과 같다. 2011년 잣 버섯 수집균주 중 다발성인 GMNL66037의 포자에 서 40 개의 단핵균주를 분리하여 그 중 균사활력이 강한 1번을 선발하고, 대가 굵은 GMNL66014의 포

*Corresponding author: dkhtjh@korea.kr 


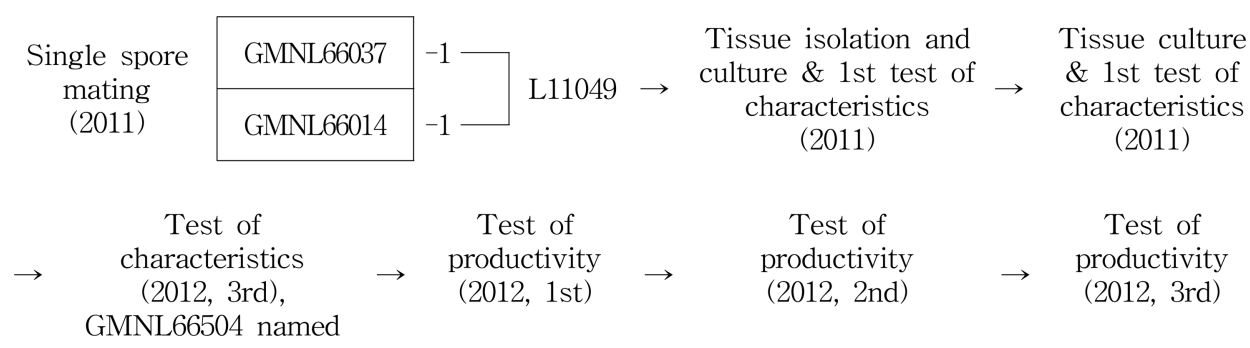

Fig. 1. The pedigree of 'Gonji10ho' bred by monokaryon-monokaryon mating.

Table 1. Inherent characteristics of 'Gonji10ho'

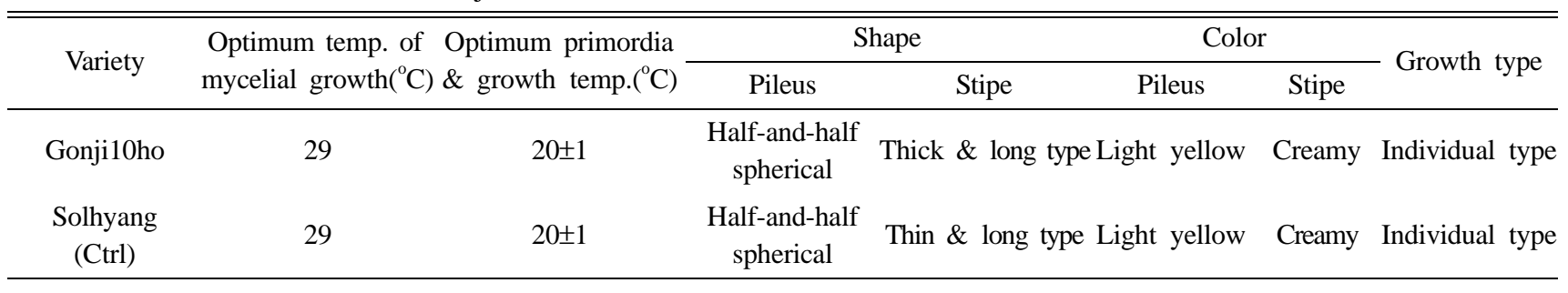

자에서 40 개의 단핵균주를 분리하여 그 중 균사 활 력이 강한 1번을 선발하였다. 선발된 GMNL66037-1 과 GMNL66014-1의 단핵균주들을 교잡하여 교잡균 주의 자실체를 조직분리하였다. 조직분리된 교잡균주 를 2011년부터 2012년까지 3차 특성 검정을 거쳐 GMNL66504 계통명을 부여하고 3차 생산력 검정을 거쳐 농촌진흥청 직무육성품종심의회에서 신품종으 로 선정되어 ‘곤지10호(Gonji10ho)'로 명명, 2013년 품종보호출원하였다.

품종 육성 방법에 있어서는, 단핵균주 선발은 포자 를 멸균수를 이용하여 희석 평판한 뒤 $\mathrm{PDA}$ 평판배지 에서 배양하여 균사끼리 서로 붙지 않은 독립된 단핵 균사를 분리하였으며, 분리된 단핵균사를 역시 PDA 평판배지에서 배양하여 400 배 광학현미경을 이용하 여 클램프 커넥션 유무를 확인하여 클램프 커넥션이 없는 균사만 선발하였다. 교잡계통의 조직분리는 단 포자를 교잡하여 작성된 교잡계통에서 특성을 대표 할 수 있는 자실체 한 개체를 취하여 조직을 분리하 여 PDA평판배지에서 배양하였다.

종균배지와 생육배지는 동일하게 미송톱밥+옥분 $(90: 10 \mathrm{v} / \mathrm{v})$ 을 혼합하여 수분함량을 $65 \%$ 로 조절하였 으며, 배지 살균방법은 $121^{\circ} \mathrm{C}, 1.2$ 기압에서 90 분간

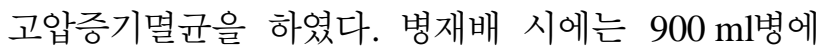
병 포함 $600 \mathrm{~g}$ 씩, 봉지재배 시에는 비닐봉지(P.P)에 $1 \mathrm{~kg}$ 씩 배지를 담아 살균하여 $22 \pm 1^{\circ} \mathrm{C}$ 의 배양실에서 35 일간 배양하였다. 배양이 완료된 후 생육실로 옮겨 온도 $20 \pm 1^{\circ} \mathrm{C}$, 습도 $94 \pm 2 \%, \mathrm{CO}_{2}$ 농도 $1,000 \pm 200 \mathrm{ppm}$ 의 환경조건으로 발이 및 생육시켰다. 생육특성조사
Table 2. Mycelial growth in the different incubation temperature. (Unit : $\mathrm{mm} / 7$ days)

\begin{tabular}{ccccccc}
\hline $\begin{array}{c}\text { Incubation } \\
\text { temperature } \\
\text { Variety }\end{array}$ & $20^{\circ} \mathrm{C}$ & $23^{\circ} \mathrm{C}$ & $26^{\circ} \mathrm{C}$ & $29^{\circ} \mathrm{C}$ & $32^{\circ} \mathrm{C}$ & $35^{\circ} \mathrm{C}$ \\
\hline Gonji10ho & 47.4 & 64.2 & 75.1 & 80.0 & 67.8 & 60.0 \\
Solhyang & 49.0 & 64.9 & 75.5 & 81.2 & 74.9 & 68.2 \\
\hline
\end{tabular}

※ Values were measured by the diameter of mycelial colony incubated for 7 days on PDA(potato dextrose agar) medium.

는 잣버섯에 대해서는 아직 조사요령이 정립이 안 되 어 있어서 국립종자원의 느티만가닥버섯 신품종특성 조사요령을 준용하여 조사하였다.

자실체 색도는 Spectrophotometer(CM-2600d, Konika minota), 물리성은 Sun rheo meter(COMPAC-100, Sun scientific co.)를 사용하여 측정하였으며, 저장성 은 수확한 버섯을 플라스틱 포장용기에 $200 \mathrm{~g}$ 씩 담고 랩포장을 하여 $4^{\circ} \mathrm{C}$ 저온저장고에서 보관하면서 저장 정도를 Minamide법(南出 등. 1980)을 이용하여 조사 하였다.

\section{결과 및 고찰}

\section{고유특성}

'곤지 10 호' 균사생장적온은 $\mathrm{PDA}$ 평판배지에서 $29^{\circ} \mathrm{C}$, 버섯발생 및 생육온도는 $20 \pm 1^{\circ} \mathrm{C}$ 로 대조품종(‘솔향’)과 같았으며, 균사 활력은 대조품종과 비슷하였다(Table 1 , 
2). 갓형태는 반반구형이며, Hunter 색체값으로 볼 때 갓색은 L $79.3, \mathrm{~b} 24.8$, 대색은 L 84.3, b 10.9로, 갓색에 있어서 대조품종에 비하여 황색도가 더 높았다(Table 1, 3). 발생형태는 대조품종과 같이 개체형이었다.

\section{배양 및 생육 특성}

병재배 시 배양 및 생육 특성을 보면, 균 배양일수 는 $22 \pm 1^{\circ} \mathrm{C}$ 에서 35 일, 초발이소요일수는 $20 \pm 1^{\circ} \mathrm{C}$ 에서 15 일, 자실체 생육일수는 온도 $20 \pm 1{ }^{\circ} \mathrm{C}$, 습도 $94 \pm 2 \%$, $\mathrm{CO}_{2}$ 농도 $1,000 \pm 200 \mathrm{ppm}$ 에서 12 일로 재배일수는 62 일이 되어 대조품종보다 2 일 길었다(Table 4). 자실체 주요 생육 특성에서 갓두께 $6.3 \mathrm{~mm}$, 대직경 $21.6 \mathrm{~mm}$, 대길이 $110.5 \mathrm{~mm}$ 로 대조품종보다 갓은 두껍고 대는 굵어 품질이 우수하였다. 유효경수는 병당 3.4개로 대조품종의 7.3개보다 적었다(Table 5).

\section{푸른곰팡이병 발생정도}

잣버섯에서 주 병해는 푸른곰팡이(Trichoderma spp.) 병으로, 재배접종 후 배양 및 생육 중 푸른곰팡이 발 생률이 $4.9 \%$ 로 대조품종 $9.1 \%$ 보다 낮았다(Table 6).

\section{수량성}

병 및 봉지재배로 3 차에 걸쳐 생산력을 검정한 결

Table 3. Hunter color value of fruiting body

\begin{tabular}{ccccccc}
\hline \hline \multirow{2}{*}{ Variety } & \multicolumn{3}{c}{ Pileus } & \multicolumn{3}{c}{ Stipe } \\
\cline { 2 - 7 } & $\mathrm{L}$ & $\mathrm{a}$ & $\mathrm{b}$ & $\mathrm{L}$ & $\mathrm{a}$ & $\mathrm{b}$ \\
\hline Gonji10ho & 79.3 & 2.6 & 24.8 & 84.3 & -0.2 & 10.9 \\
Solhyang & 84.1 & -1.2 & 10.6 & 85.0 & -0.2 & 10.1 \\
\hline ※ Measured by & spectrophotometer(CM-3600d), Konika minolta, L : \\
brightness, a : red(+)/green(-), b : yellow(+), blue(-).
\end{tabular}

Table 4. Cultivation period according to growth stage (Unit : days)

\begin{tabular}{ccccc}
\hline \hline Variety & $\begin{array}{c}\text { Spawn } \\
\text { run } \\
\text { period }\end{array}$ & $\begin{array}{c}\text { Primordia } \\
\text { formation } \\
\text { period }\end{array}$ & $\begin{array}{c}\text { Fruiting body } \\
\text { development } \\
\text { period }\end{array}$ & $\begin{array}{c}\text { Cultivation } \\
\text { period }\end{array}$ \\
\hline Gonji10ho & 35 & 15 & 12 & 62 \\
Solhyang & 35 & 14 & 11 & 60 \\
\hline
\end{tabular}

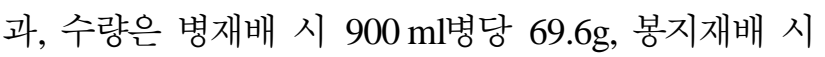
$1 \mathrm{~kg}$ 봉지당 $114.2 \mathrm{~g}$ 으로 대조품종 대비 $38 \%$ 와 $10 \%$ 씩 증수되었다(Table 7,8 ). 증수 요인은 대조품종 대 비 개체수는 적으나 개체중이 무겁기 때문인 것으로 분석된다.

\section{물리적 특성 및 저장성}

물리적 특성에서 갓의 강도 및 취성은 대조품종에 비하여 높았고 대의 물리성은 대조품종과 비슷하였 다(Table 9).

저장성은 $200 \mathrm{~g}$ 랩포장으로 $4^{\circ} \mathrm{C}$ 에서 저장하여 Minamide법으로 본 신선도를 기준으로 하여 조사한 결과 판매가능기간으로 볼 때 34일로 대조품종에 비 하여 5일이 길었다(Table 10).

\section{대선 형성 및 $\mathrm{DNA}$ 다형성 검정}

'곤지 10 호'와 대조품종의 균사를 대치배양했을 때 두

Table 6. Occurrence rate of Trichoderma spp. during cultivation (Unit : \%)

\begin{tabular}{ccccc}
\hline \hline Variety & 1st & 2nd & 3rd & Average \\
\hline Gonji10ho & 5.0 & 4.2 & 5.4 & 4.9 \\
Solhyang & 8.9 & 9.5 & 8.8 & 9.1 \\
\hline
\end{tabular}

※Occurrence rate of Trichoderma spp.(\%) = The number of bottles infected / The number of total bottles tested(100EA) $\times 100$.

Table 7. Yield of 'Gonji10ho' in the bottle cultivation. ('12. productivity test, unit : g/900 $\mathrm{ml}, \varnothing 65 \mathrm{~mm}$ bottle)

\begin{tabular}{ccccccc}
\hline \hline Variety & 1st & 2nd & 3rd & C.V. & Average & index \\
\hline Gonji10ho & 71.5 & 69.8 & 67.4 & 3.0 & $69.6 \mathrm{a}^{\mathrm{a}}$ & 138 \\
Solhyang & 49.0 & 52.7 & 50.0 & 3.8 & $50.6 \mathrm{~b}$ & 100 \\
\hline${ }^{\mathrm{a}}$ DMRT at 5\% level & & & & &
\end{tabular}

Table 8. Yield of 'Gonji10ho' in the bag cultivation. (' 12. productivity test, unit : $\mathrm{g} / 1 \mathrm{~kg} \mathrm{bag}$ )

\begin{tabular}{ccccccc}
\hline \hline Variety & 1 st & 2nd & 3rd & C.V. & Average & index \\
\hline Gonji10ho & 115.5 & 110 & 117.2 & 3.3 & $114.2 \mathrm{a}^{\mathrm{a}}$ & 110 \\
Solhyang & 99.5 & 105.9 & 106.5 & 3.7 & $104.0 \mathrm{~b}$ & 100 \\
\hline
\end{tabular}

${ }^{\mathrm{a}}$ DMRT at $5 \%$ level.

Table 5. Morphological characteristics of fruiting body in the bottle cultivation

\begin{tabular}{cccccccc}
\hline \hline \multirow{2}{*}{ Variety } & \multicolumn{3}{c}{ Pileus } & \multicolumn{2}{c}{ Stipe } & \multicolumn{2}{c}{ Availablle stipe } \\
\cline { 2 - 7 } & $\begin{array}{c}\text { Thickness } \\
(\mathrm{mm})\end{array}$ & $\begin{array}{c}\text { Diameter } \\
(\mathrm{mm})\end{array}$ & $\begin{array}{c}\text { Thickness/ } \\
\text { Diameter }\end{array}$ & $\begin{array}{c}\text { Diameter } \\
(\mathrm{mm})\end{array}$ & $\begin{array}{c}\text { Length } \\
(\mathrm{mm})\end{array}$ & $\begin{array}{c}\text { Diameter/ } \\
\text { length }\end{array}$ & $\begin{array}{c}\text { number } \\
\text { (per bottle) }\end{array}$ \\
\hline Gonji10ho & 6.3 & 52.0 & 0.12 & 21.6 & 110.5 & 0.20 & 3.4 \\
Solhyang & 5.0 & 52.2 & 0.10 & 14.8 & 104.5 & 0.14 & 7.3 \\
\hline
\end{tabular}


Table 9. Physical characteristics of fruiting body

\begin{tabular}{ccccccc}
\hline \hline \multirow{2}{*}{ Variety } & \multicolumn{3}{c}{ Pileus } & \multicolumn{3}{c}{ Stipe } \\
\cline { 2 - 8 } & $\begin{array}{c}\text { Strength } \\
\left(\mathrm{g} / \mathrm{cm}^{2}\right)\end{array}$ & $\begin{array}{c}\text { Springness } \\
(\%)\end{array}$ & $\begin{array}{c}\text { Brittleness } \\
(\mathrm{g})\end{array}$ & $\begin{array}{c}\text { Strength } \\
\left(\mathrm{g} / \mathrm{cm}^{2}\right)\end{array}$ & $\begin{array}{c}\text { Springness } \\
(\%)\end{array}$ & $\begin{array}{c}\text { Brittleness } \\
(\mathrm{g})\end{array}$ \\
\hline Gonji10ho & 127 & 94.9 & 4,215 & 1,012 & 97.3 & 65,193 \\
\hline Solhyang & 102 & 92.4 & 3,622 & 993 & 96.1 & 64,367 \\
\hline
\end{tabular}

※ Measured by Sun rheo meter(COMPAC-100), Sun scientific co..

Table 10. Storage characteristics of fruiting body (Unit : Freshness degree)

\begin{tabular}{|c|c|c|c|c|c|c|c|c|c|c|c|c|c|c|c|c|c|}
\hline Variety & Days in storage & 0 & 5 & 10 & 11 & 16 & 17 & 20 & 21 & 25 & 29 & 30 & 34 & 35 & 40 & 45 & 50 \\
\hline & Gonji10ho & 10 & 10 & 10 & 8 & 8 & 8 & 8 & 6 & 6 & 6 & 6 & 6 & 4 & 4 & 2 & 0 \\
\hline & Solhyang & 10 & 10 & 10 & 8 & 8 & 6 & 6 & 6 & 6 & 6 & 4 & 4 & 4 & 2 & 0 & 0 \\
\hline
\end{tabular}

※ Freshness degree(Minamide method) : 10 ; Very fresh, 8 ; Fresh, 6 ; Available for sale, 4 ; Edible, 2 ; Not edible, 0 ; Rotten. ※ Storage temperature : $4^{\circ} \mathrm{C}$, Storage unit pack : LDPE plastic wrap $/ 200 \mathrm{~g}$.

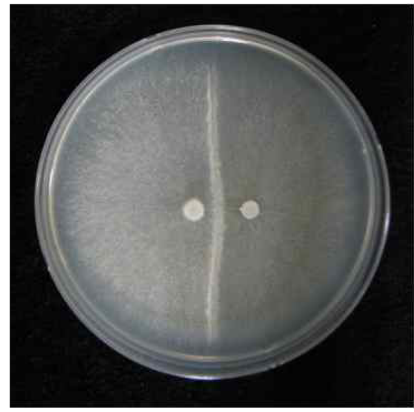

Gonji10ho(left)+ Solhyang(right)

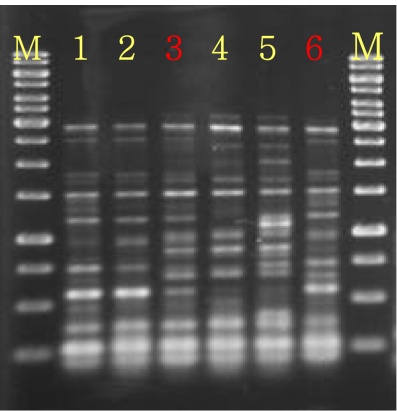

Primer UFPF3

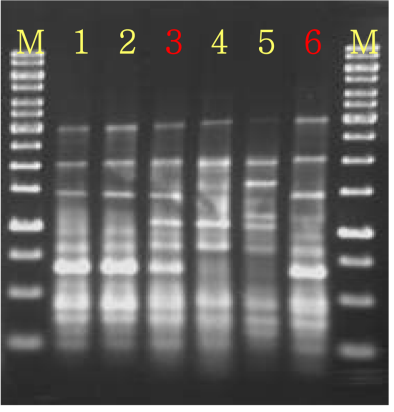

Primer UFPF5

※ DNA patterns- M: Marker, 1: GMNL66037, 2: GMNL66037-1(monokaryon), 3: Gonji10ho, 4: GMNL66014-1(monokaryon), 5: GMNL66014, 6: Solhyang.

Fig. 2. Dual culture and random amplified polymorphic DNA patterns by primers.

품종간 확실한 대선을 형성하였으며, $\mathrm{DNA}$ 를 $\mathrm{UFPF}$ 프라이머를 사용하여 PCR로 증폭하고 이를 전기영동 으로 분리하여 증폭산물의 다형성을 비교 분석한 결 과, '곤지10호'는 모본 GMNL66037, GMNL66014 및 대조품종과 DNA밴드 양상의 차이를 나타내었다 (Fig. 2). 이상의 결과로 '곤지 10 호'와 대조품종은 형 질이 다른 품종임을 확인할 수 있었다.

\section{적 요}

잣버섯의 다수성 신품종 개발을 위하여, 단포자교 잡에 의해 육성된 신품종 '곤지 10 호'의 주요 특성은 다음과 같다.

균사생장적온은 $29^{\circ} \mathrm{C}$, 버섯 발생 및 생육온도는 $20 \pm 1^{\circ} \mathrm{C}$ 로 대조품종과 같았으며, 균사 활력도 대조품
종과 비슷하였다. 갓형태는 반반구형이며, Hunter 색 체값으로 볼 때 갓색은 $\mathrm{L} 79.3, \mathrm{~b} 24.8$, 대색은 $\mathrm{L}$ 84.3, b 10.9로, 갓색에 있어서 대조품종에 비하여 황 색도가 더 높았다. 미송톱밥+옥분(90:10, v/v)배지로 병재배 시 배양일수는 $22 \pm 1^{\circ} \mathrm{C}$ 에서 35 일, 발이일수와 자실체생육일수는 $20 \pm 1^{\circ} \mathrm{C}$ 에서 15 일과 12 일로 재배 일수는 62 일이 되어 대조품종보다 2일 길었다. 자실 체 생육 특성은 대조품종에 비하여 갓두께는 $6.3 \mathrm{~mm}$ 로 두꺼웠으며, 유효경수는 3.5 개로 적었고 대 직경 은 $21.6 \mathrm{~mm}$ 로 굵었다. 재배접종 후 배양 및 생육 중 푸른곰팡이병(Trichoderma spp.) 발생율은 $4.9 \%$ 로 대조품종보다 낮았다. 수량은 생산력 검정 결과 병재 배 시 $900 \mathrm{ml}$ 병당 $69.6 \mathrm{~g}$, 봉지재배 시 $1 \mathrm{~kg}$ 봉지당 $114.2 \mathrm{~g}$ 으로 대조품종 대비 $38 \%$ 와 $10 \%$ 씩 많았다. 자실체 물리성에서 갓의 강도와 취성이 대조품종 
보다 강했고, 저장성은 판매가능기간으로 볼 때 34 일 로 대조품종에 비하여 5 일 길었다.

\section{감사의 말슴}

이 논문은 농촌진흥청 공동연구사업 농업현장실용화 기술 개발 협동연구개발과제(과제번호: PJ907021062013) 출연금 지원에 의하여 이루어진 것으로 이에 감사드 립니다.

\section{참고문헌}

김성원. 1979. 잣버섯이 성분 연구(I). 한국균학회지. 7 : 9-11. 장명준. 2011. 잣버섯의 생리생태적 특성 및 재배환경에 관한 연구. 공주대학교 대학원 박사학위논문.

장명준, 이한범, 이윤혜, 박수옥, 주영철. 2010a. 잣버섯 재배 법 개발에 관한 연구. 2009년도 시험연구보고서(경기도농 업기술원). 672-694.

장명준, 이한범, 이윤혜, 김정한, 주영철. $2010 \mathrm{~b}$. 잣버섯 생육 에 적합한 환경조건 구명. 2009년도 시험연구보고서(경기 도농업기술원). 412-418.
장명준, 이한범, 이윤혜, 주영철. 2010c. 잣버섯 종균 제조기 술 개발('솔향' 생산판매 신고). 2009년도 시험연구보고서 (경기도농업기술원). 665-671.

진미림, 정규선. 1999. 잣버섯 자실체로부터 분리한 수용성 단백다당체 lepidan의 면역 증가 작용. 약학회지. 43 : 635641.

Choi, J. J., Jin, M., Lee, J. K., Lee, W. Y., Park, Y. I., Han, Y. N. and Kim, S. Y.. 2006. Contrl of cytokin gene expression by PG101, a water-soluble extract prepared from Lentinus lepideus. Biochemical and Biophysical Research Communications. 339 : 880-887.

Jin, M., Jeon, H., Jung, H. G., Kim, B., Shin, S. S., Choi, J. J., Lee, J. K., Kang, C. Y. 2003a. Enhancement of repopulation and hematopoiesis of bone marrow cell in irradiated mice by oral administration of PF101, a watersoluble extract from Lentinus lepideus. Experimental Biology and Medicine. 228 : 759-766.

Jin, M., Jung, H. J., Choi, J. J., Jeon, H., Oh, J. W., Kim, B., Shin, S. S., Lee, J. K., Yoon, K. and Kim, S. Y. 2003b. Activation of selective transcription and cytokines by water-soluble extracts from Lentinus lepideus. Experimental Biology and Medicine. 228 : 749-758.

南出陸久, 抗生後夫, 緒方邦安. 1980. 數種キノコ 類の 鮮度 にむよほおす 貯藏溫度 影響. 日食工誌 27 : 281-287. 